УДК: 7.0337 .04745

ББК: 85.123

A43

DOI: $10.18688 / \mathrm{aa} 177-2-25$

Renate Rosenthal-Heginbottom

\title{
Pilgrim Mementoes from the Holy Land: Production, Iconography, Use and Distribution
}

From the $4^{\text {th }}$ century CE onwards, there was a substantial increase in the number of pilgrims visiting the Holy Land [51, pp. 229-230; 52, p.4], and naturally most pilgrims desired to take back with them some sacred and magical mementoes. Such objects are called 'eulogiai', in Greek 'blessings'. In the $4^{\text {th }}$ century, eulogia is described as actual experience at the Holy Places (like being baptized in the Jordan River or eating a meal at the place of the Last Supper). In the $6^{\text {th }}$ century, eulogiai became physical objects sanctified by contact with the divine [52, pp.13-15]. They comprise a variety of artefacts like flasks and spouted juglets, bread stamps and tokens. Mostly made of clay, they were relatively cheap keepsakes produced and sold at and near shrines and sanctuaries. The imagery depicted and the inscriptions included were related to the holy places; in their vicinity local workshops were established by artisans and craftsmen who specialized in the production of such objects which, in the words of John of Damascus, "are receptacles of divine power" [38, p. 198]. Particularly prevalent were ampullae, small clay flasks filled with holy water, oil or other substances. The visitors took them home and cherished them as a sort of miracle-working relics to protect and heal, and to ward off evil.

Apart from the many Christian pilgrim sites in the Holy Land, there were three global Christian pilgrimage centres with their distinct eulogiai: the Shrine of Saint Menas in Egypt, the Shrine of St. John the Evangelist in Asia Minor at Ephesus, and the monastic sites of the two Saints Symeon the Stylites in northern Syria [for illustrations see 21, pp. 202-203; 54, p. 103]. A fourth group of pilgrimage art is represented by the fair number of the Monza-Bobbio lead ampullae with imagery related to the Church of the Holy Sepulchre in Jerusalem, where most likely they were manufactured during the $6^{\text {th }}$ and $7^{\text {th }}$ centuries CE $[13 ; 14 ; 23 ; 51$, pp. 236-243; 52, pp.36-40]. During his visit to that church the anonymous pilgrim from Piacenza (c. 570 CE) reports a contact ritual: "....and they offer oil to be blessed in little flasks. When the mouth of one of the little flasks touches the Wood of the Cross, the oil instantly bubbles over, and unless it is closed very quickly, it all spills out." [51, pp. 234-235; see also the discussion in 23, pp.232-234]. The function of the eulogiai is clear: they were a blessing by virtue of the contact with a holy site, a holy person, or a relic that infused them with a miracle-working potential." [51, p. 234].

Pilgrim mementoes from Jerusalem and the Holy Land comprise flasks and spouted juglets, bread stamps and tokens. The flasks are discussed in detail, while specimens of the other artefact classes are referred to summarily. On the basis of the finds from excavations and objects in 
Museum collections it is possible to define five distinct stylistic and iconographic groups (see Table 1). In imagery and elements of decoration they combine characteristic features of Byzantine visual arts prevalent in the Holy Land. It is postulated here that they were manufactured locally.

Table 1. Distribution list of ampullae

Group 1 - moulds;

Group 2 - pictorial representations;

Group 3 - linear style and imagery arranged in tiers;

Group 4 - linear style with crosses, birds, rosettes and geometric patterns;

Group 5 - plain vessels.

${ }^{\star}$ Decorative elements described from top to bottom

${ }^{*}$ Vessels with same scene or pattern on either side of the body

\begin{tabular}{|c|c|c|c|c|}
\hline Group & No. & Find-spot/collection/Reg.-nos. & Description & Publication \\
\hline 1 & 1 & Jerusalem, Silwan village & $\begin{array}{l}\text { Side A: Sacrifice of Isaac; Side B: } \\
\text { Daniel in the Lions' Den }\end{array}$ & 37 , fig. 1 \\
\hline 1 & 2 & Jerusalem, Mount Zion & Undecorated & 37 , fig. 2 \\
\hline 1 & $\begin{array}{c}3 \\
\text { Fig. } 1\end{array}$ & Caesarea & Cross within schematic wreath & 36, no. 7 \\
\hline 2 & $4^{\star *}$ & $\begin{array}{l}\text { Unknown provenance } \\
\text { IAA } 65-434\end{array}$ & $\begin{array}{l}\text { Annunciation scene within } \\
\text { inscription; height } 10 \mathrm{~cm}\end{array}$ & $\begin{array}{l}20 ; \\
21, \text { pp. } 148,223 ; \\
42 \text {, pl. } 8 \text { A }\end{array}$ \\
\hline 2 & 5 & Damascus National Museum & $\begin{array}{l}\text { probably made from the same mould } \\
\text { as no. } 4 ; \\
\text { height } 10 \mathrm{~cm}\end{array}$ & $\begin{array}{l}23, \text { p. } 239 \\
48, \text { no. } 225\end{array}$ \\
\hline 2 & 6 & $\begin{array}{l}\text { Jerusalem, south of Temple } \\
\text { Mount }\end{array}$ & $\begin{array}{l}\text { Inscription referring to St. Elizabeth's } \\
\text { flight }\end{array}$ & 11, pl. I. $19: 4$ \\
\hline $3^{*}$ & $7^{\star *}$ & Unknown provenance & $\begin{array}{l}\text { Side A - cross flanked by two palm } \\
\text { branches; arcade of three arches; } \\
\text { bird pecking at a tendril; inscription } \\
\text { in retrograde; Side B - same pattern, } \\
\text { different inscription in retrograde; } \\
\text { height } 10 \mathrm{~cm}\end{array}$ & 19, no. 353 \\
\hline $3^{*}$ & 8 & $\begin{array}{l}\text { Unknown provenance } \\
\text { IAA P. } 1335\end{array}$ & $\begin{array}{l}\text { Three crosses; arcade of three arches; } \\
\text { inscription in retrograde; bird; } \\
\text { extant height } 8 \mathrm{~cm}\end{array}$ & $21, \mathrm{pp} \cdot 202,225 \mathrm{~g}$ \\
\hline $3^{*}$ & 9 & Acquired in Egypt & $\begin{array}{l}\text { Three crosses; arcade of three arches; } \\
\text { inscription in retrograde (broken) }\end{array}$ & 56, no. 1409 \\
\hline $3^{*}$ & 10 & $\begin{array}{l}\text { Jerusalem, building south of } \\
\text { Temple Mount }\end{array}$ & $\begin{array}{l}\text { Fragment: arcade with lower part } \\
\text { of two arches; broken inscription in } \\
\text { retrograde }\end{array}$ & 12 , fig. 3.1 \\
\hline
\end{tabular}




\begin{tabular}{|c|c|c|c|c|}
\hline Group & No. & Find-spot/collection/Reg.-nos. & Description & Publication \\
\hline 3 & 11 & Khirbet Es-Suyyagh & $\begin{array}{l}\text { Fragment: arcade of at least two } \\
\text { arches; palm branches beneath }\end{array}$ & 49, fig. 3.21:4 \\
\hline 3 & 12 & Acquired in Smyrna & $\begin{array}{l}\text { Bust with Orientalizing face flanked } \\
\text { by two palm branches; } \\
\text { height } 11.5 \mathrm{~cm}\end{array}$ & 33, no. 156 \\
\hline $3^{*}$ & 13 & Bought in Jerusalem & $\begin{array}{l}\text { Front side: Orientalizing head flanked } \\
\text { by two palm branches; two peacocks; } \\
\text { rear side: four concentric circles; } \\
\text { extant height } 8.1 \mathrm{~cm}\end{array}$ & 19, no. 354 \\
\hline 3 & $14^{\star *}$ & $\begin{array}{l}\text { Terra Sancta Museum, } \\
\text { Jerusalem }\end{array}$ & $\begin{array}{l}\text { The Calvary: schematic depiction of a } \\
\text { rock with three crosses on top }\end{array}$ & 3, fig. 210 \\
\hline 3 & 15 & Jerusalem, Silwan & $\begin{array}{l}\text { Fragment: front side large cross } \\
\text { with palm branch behind, to right } \\
\text { cross; rear side cross within circle } \\
\text { surrounded by circle of small bows } \\
\text { and a herring-bone pattern }\end{array}$ & 5, fig. 17 \\
\hline 3 & 16 & Jerusalem, Mt. Zion & $\begin{array}{l}\text { Two fragments of the front and rear } \\
\text { sides of no. } 15\end{array}$ & $\begin{array}{l}\text { 5, fig. } 16 \text { centre } \\
\text { and right }\end{array}$ \\
\hline 3 & 17 & Jerusalem, Mt. Zion & Fragment: decoration not clear & 5, fig. 16 left \\
\hline $3^{*}$ & $18^{\star *}$ & $\begin{array}{l}\text { Einabus, Samaria (reportedly) } \\
\text { IAA } 42.92\end{array}$ & $\begin{array}{l}\text { Cross flanked by birds; three } \\
\text { amphorae; two palm branches } \\
\text { between three columns (?), height } \\
13.5 \mathrm{~cm}\end{array}$ & $\begin{array}{l}21, \text { pp. } 202, \\
225 \mathrm{~d} ; \\
30, \text { fig. } 86\end{array}$ \\
\hline 4 & 19 & $\begin{array}{l}\text { Hamat Tiberias } \\
\text { IAA } 56-1715\end{array}$ & $\begin{array}{l}\text { Cross enclosed by beaded circle; } \\
\text { height } 7 \mathrm{~cm}\end{array}$ & 21, pp. $202,225 c$ \\
\hline 4 & 20 & $\begin{array}{l}\text { Castra } \\
\text { IAA 98-2267 }\end{array}$ & $\begin{array}{l}\text { Cross within schematic wreath; height } \\
12 \mathrm{~cm}\end{array}$ & 57, p. 25 \\
\hline 4 & 21 & Jerusalem & $\begin{array}{l}\text { Cross within schematic wreath; height } \\
7 \mathrm{~cm}\end{array}$ & 6, pl.XXVII:40 \\
\hline 4 & $\begin{array}{c}22 \\
\text { Fig. } 2\end{array}$ & Jerusalem, Peristyle House & $\begin{array}{l}\text { In centre rosette of rays within } \\
\text { schematic wreath; four dotted semi- } \\
\text { circles, the upper and lower ones with } \\
\text { a bird, within schematic wreath }\end{array}$ & 31, fig. 15.3:27 \\
\hline 4 & $\begin{array}{c}23 \\
\text { Fig. } 3\end{array}$ & Jerusalem, Mt. Zion & $\begin{array}{l}\text { Fragment: dotted semi-circle with } \\
\text { bird and schematic wreath, same style } \\
\text { as no. } 22\end{array}$ & Unpublished \\
\hline 4 & 24 & Jerusalem, Ophel & $\begin{array}{l}\text { Fragment: dotted semi-circle and } \\
\text { schematic wreath }\end{array}$ & 17, fig. 1.5.1:194 \\
\hline
\end{tabular}




\begin{tabular}{|c|c|c|c|c|}
\hline Group & No. & Find-spot/collection/Reg.-nos. & Description & Publication \\
\hline 4 & $25^{\star \star}$ & Damascus National Museum & $\begin{array}{l}\text { In centre rosette composed of rays } \\
\text { with dots in between, surrounded by } \\
\text { two schematic wreaths; the central } \\
\text { motif like no. } 21 \text {; height } 9.5 \mathrm{~cm}\end{array}$ & 15, no. 121 \\
\hline 4 & 26 & $\begin{array}{l}\text { St. Anne Museum, } \\
\text { Jerusalem, PB } 3641 \text { (from the } \\
\text { Lebanon) }\end{array}$ & $\begin{array}{l}\text { Four-petalled rosette in cross shape } \\
\text { enclosed by row of dots with two } \\
\text { circles; height } 10.5 \mathrm{~cm}\end{array}$ & 21, pp. $202,225 \mathrm{e}$ \\
\hline 4 & 27 & Jerusalem & $\begin{array}{l}\text { Fragment: seven-petalled central } \\
\text { rosette within schematic wreath }\end{array}$ & 8 , fig. $3.4: 7$ \\
\hline 4 & $\begin{array}{c}28 \\
\text { Fig. } 4\end{array}$ & Ramat Rahel & $\begin{array}{l}\text { Fragment of centre: seven-petalled } \\
\text { rosette with dotted circle; height } \\
9.5 \mathrm{~cm}\end{array}$ & 1, fig. 10:9 \\
\hline 4 & $29^{* *}$ & $\begin{array}{l}\text { Ramat Rahel } \\
\text { IAA 67-1173/1 }\end{array}$ & $\begin{array}{l}\text { Two beaded circles and central circle } \\
\text { filled with four dots arranged in cross- } \\
\text { shape }\end{array}$ & $\begin{array}{l}\text { 1, fig. } 10: 11 \\
21, \text { pp. } 202 \\
225 \text {; } \\
27, \text { p. } 259\end{array}$ \\
\hline 4 & 30 & Jerusalem, Tyropoeon Valley & $\begin{array}{l}\text { Fragment: beaded circles, style of no. } \\
28\end{array}$ & 7, pl. 16:31 \\
\hline 4 & 31 & Jerusalem & $\begin{array}{l}\text { Fragment: beaded circle, probably } \\
\text { style of no. } 28\end{array}$ & 17, fig. 1.5.1:215 \\
\hline 4 & 32 & Jerusalem & $\begin{array}{l}\text { Fragment: rosette composed of rays or } \\
\text { spoked wheel, the shape of the neck is } \\
\text { like no. } 21\end{array}$ & 8, fig. 3.4:6 \\
\hline 4 & 33 & Capernaum & $\begin{array}{l}\text { Fragment with schematic wreath, } \\
\text { probably like no. } 28\end{array}$ & $\begin{array}{l}25, \text { p. } 135, \text { no. } 7 \\
26, \text { p. } 82, \text { no. } 19\end{array}$ \\
\hline 4 & 34 & Jerusalem & $\begin{array}{l}\text { Fragment: on shoulder two stamped } \\
\text { flowers }\end{array}$ & 32, pl. I. $16: 40$ \\
\hline 5 & 35 & $\begin{array}{l}\text { Beth Shean } \\
\text { IAA 99-3783 }\end{array}$ & $\begin{array}{l}\text { Undecorated; } \\
\text { height } 8 \mathrm{~cm}\end{array}$ & 21, pp. $202,225 \mathrm{a}$ \\
\hline 5 & 36 & $\begin{array}{l}\text { St. Anne Museum, Jerusalem, } \\
\text { PB } 3642\end{array}$ & $\begin{array}{l}\text { Undecorated; } \\
\text { height } 7.5 \mathrm{~cm}\end{array}$ & 21, pp. $202,225 f$ \\
\hline
\end{tabular}

\section{Group 1 - moulds}

Moulds provide the most reliable evidence to determine the existence of local workshops. A lime-stone mould found in the Silwan village (Jerusalem), received through an antiquities dealer, is decorated with the Sacrifice of Isaac on one side and Daniel in the Lion's Den on the other (Table 1, no. 1) [14, p. 159, fig. 1, pl. 9a, b; 37, p. 585, fig. 1]. The imagery is clarified by inscriptions [14, pp. 161-162]. The first reads 'EY $\Lambda$ ОГIA TOY ABPAAM' (eulogia of Abraham), the second 'O AГIOC $\triangle$ ANIIA $\Lambda$ ' (Daniel the Holy) and 'EY $\Lambda$ OГIA TOY $\triangle$ ANII $\Lambda$ ' (eulogia of 


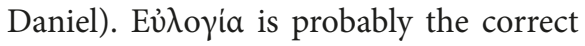
reading of the letters EY $\Gamma$ on a flask fragment from a late Byzantine building south of the Temple Mount (Table 1, no. 10) [12]. The subjects on the mould are prominent Old Testament themes not only in Christian but also in Jewish art during the Byzantine period [18, pp. 288-292 for Abraham, pp. 294-295 for Daniel].

Two additional lime-stone moulds for flasks were found, an undecorated one in the Latin cemetery on Mt. Zion (Table 1, no.2) [37, p.586, fig. 2] and another at Caesarea, decorated with a cross on each side (Fig. 1; Table 1, no.3) [36, p.300, no.7]; see also the flasks with crosses from Hamat Tiberias (Table 1, no. 19), from Castra (Table 1, no. 20), from Jerusalem (Table 1, no. 21) and from a probable east-

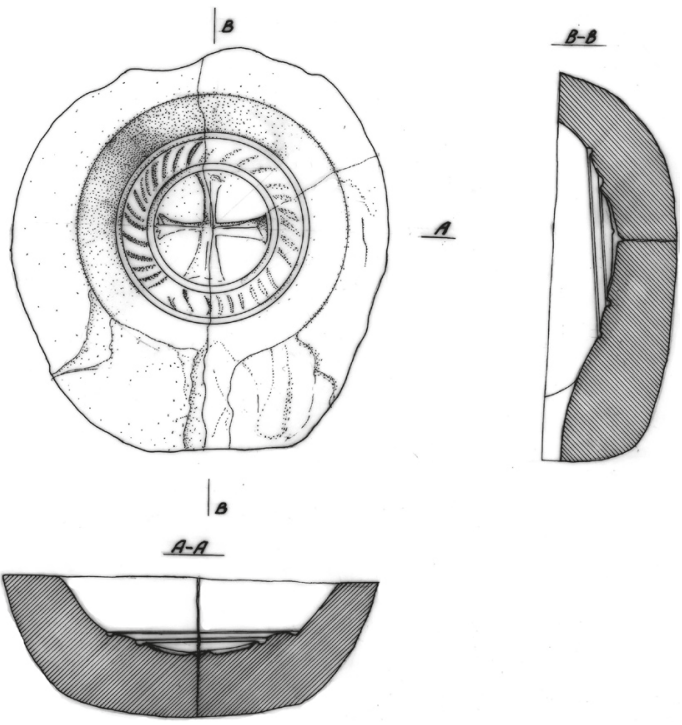

Fig. 1. Lime-stone mould from Caesarea. Courtesy of J. Patrich ern Mediterranean workshop [21, p. 127; 54, no. 104].

\section{Group 2 - pictorial representations}

The inscribed flask was acquired from an antiquity dealer in Jerusalem and is now in the Israel Museum. On both sides of the flask the Annunciation is shown: Mary is seated on a high-backed chair and the angel is standing in front of her (Table 1, no. 4). The subject suggests the attribution to Nazareth, the location of the announcement by the archangel Gabriel that Mary would conceive and become the mother of Jesus [2, pp.154-156; 20, pp. 112-113; 21, p. 148 bottom row; 42, fig. 1, pl. 8A]. The inscription reads: +XEPEKAIXAPITOMENHOKYP-

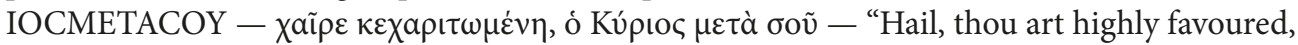
the Lord is with thee", Luke 1:28 [42, p.73]. The first Church of the Annunciation was constructed over the house of Mary and Joseph in the Byzantine period, and Christians celebrate the event on March $25^{\text {th }}$ to this day. A second flask, probably from the same mould, is in the National Museum of Damascus; it was found at Zabadani near Damascus (Table 1, no. 5) [23, p. 239, note $71 ; 48$, no. 225]. Different are the hand-formed attached coiled handles; the pair on the flask of unknown provenance is relatively heavy and the handles project beyond the maximum body width of the flask; the pair on the Damascus flask is smaller. The subject is well attested; see for example the silver token excavated at Caesarea [21, p. 149].

The fragment of an inscribed clay ampulla from Jerusalem refers to Saint Elizabeth's flight (Table 1, no. 6) [11, pl. 1.19:4] and can be compared to a token in the Bobbio treasury in Italy, where the inscription reads "Blessing of the Lord from the Refuge of St. Elizabeth" [52, p. 22, fig. 9]. Elizabeth and her infant John, the future John the Baptist, were miraculously hidden in a cave at 'En Karem during the Massacre of the Innocents in Bethlehem. The Stone of Hiding is 
venerated to this day in the cave of the Church of the Visitation, commemorating the visit paid by the Virgin Mary to Elizabeth.

\section{Group 3 - linear style and imagery mostly arranged in tiers}

A fairly large group of flasks comprises vessels decorated in a linear style, often arranged in four or three registers. The cross is the dominant image, the key symbol of the Christian faith with Jerusalem as the specific locus of the worship in the Church of the Holy Sepulchre. Other motifs, depicted occasionally, include birds, possibly doves, peacocks, arcades, palmettes, heads in Orientalizing style (see Fig. 5 for an example). Some vessels bear a short inscription.

The three complete or nearly complete ampullae in this group were acquired on the antiquities market (Table 1, nos.7-9), while fragments of stylistically close vessels were retrieved in Jerusalem (Table 1, nos. 10, 15-17). The intact flask of unknown provenance in the Royal Ontario Museum, Toronto, has four registers with the same imagery on either side. From top to bottom there is a cross flanked by two palm branches, an arcade of three arches, the inscription 'Kúpiع

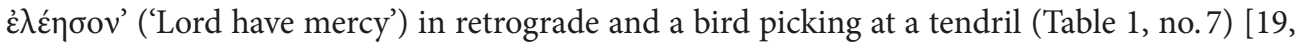
no. 353]. The tier with the arcades is the most distinct decorative element; the objects hanging down in the central arch cannot be identified securely. Found also on other flasks [see Table 1, nos. 8-9], they might represent hanging lamps [see 39, fig. 505 and 40, pp. 175, 205 for examples on the mosaic floors in the Church of Saint John at Gerasa and in the church of Tayibat al-Imam at Hama]. Two additional flasks are nearly identical to the flask in the Royal Onatario Museum. The first of unknown provenance with the lettering 'THCIONKET' in retrograde is in the IAA collections (Table 1, no. 8) [21, pp.202, 225g]. The second in the Bode Museum, Berlin, with the partly missing inscription in retrograde was acquired in Egypt (Table 1, no.9) [56, no. 1409]. A small fragment from a Late Byzantine building south of the Temple Mount can also be assigned to this style; of the arcade only the lower pillars of the right and central arch are

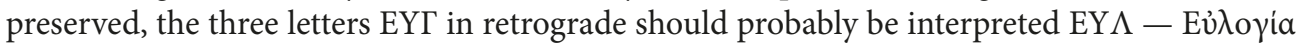
(Table 1, no.10) [12, fig.3.1]. The find-spot supports the attribution to a local workshop. A horizontal band of at least two arcades ornaments the flask from the monastery at Khirbet Es-Suyyagh in the Judean Shephelah (Table 1, no. 11) [49, fig. 3.21:4], the objects hanging down from the arch probably representing lamps. Petrographic analysis indicated that the vessel was made from marl of the Moza soil formation in a workshop in Jerusalem or its vicinity [49, p. 107].

A number of flasks with variegated imagery can stylistically be assigned to Group 3. Faces in Orientalizing style occur on an ampulla in the Louvre, acquired in Smyrna (Table 1, no. 12) [33, no. 156] and on another bought in Jerusalem (Table 1, no. 13) [19, no.354]. To date, the schematic depiction of the Calvary with three crosses, the central one larger and set higher is singular (Table 1, no. 14) [3, p. 307, fig. 210]. It is probably a local product like the fragmentary flasks from Mount Zion and Silwan village (Table 1, nos. 15-17).

The intact flask, said to be from a rock-cut tomb at Einabus, Samaria, is decorated on either side with a central cross flanked by two birds in the upper tier, three amphorae in the middle tier, and two palm branches between three columns (?) in the lower tier (Table 1, no. 18) [30, p. 209, no. 86]. On two ampullae, three crosses are set above the arcade (Table 1, nos. 8-9). Palm branches can flank the vessels' sides (Table 1, no.12). The combination of arcade, cross and 
palm branch is found on other clay artefacts, indicating that the decorative elements of flasks conform to the visual language of the Byzantine period; see, for example, the lamp with three arches filled with a palm branch in the centre and a cross on each side, which was acquired in Jerusalem [46, p. 115, no. 471].

\section{Group 4 - linear style with crosses, birds, rosettes and geometric patterns}

In this group of more than a dozen vessels all originate from excavations, with the exception of a single one, and their find-spots corroborate local production. Their style combines crosses and birds with radial and concentric elements composed of star rosettes, beaded circles, dotted lines, and rows of chevrons/herring-bone patterns (Table 1, nos. 19-34; only no. 26 was acquired on the antiquities market). Like on the mould from Caesarea the cross is the central element on three flasks from Hamat Tiberias, Castra and Jerusalem (Table 1, nos. 19-21). A complete flask of unknown provenance (height $10.5 \mathrm{~cm}$ ), decorated with a large cross and a bird on each side of the lower voids, was probably produced in an eastern workshop [54, no. 104].

The nearly complete, now lost flask from the fills of the Peristyle House to the south of the Temple Mount carries a relief decoration symmetrically arranged (Fig. 2; Table 1, no. 22) [31, pp. 152-153, 161, fig. 15.3:27]. In the centre there is a schematic rosette composed of rays, and a circle of herring-bone pattern runs close to the edge as a bordering frame; the remaining surface is filled by four semi-circles, the upper and lower ones adorned with a bird to the left; the lateral semi-circles are broken. The fills are dated "no later than the $4^{\text {th }}$ or the beginning of the $5^{\text {th }}$ century" [31, pp. 156-157]. A fragment of a similar flask with bird and semi-circle was retrieved in an assemblage of an earth fill below a plastered floor contemporary with the construction of the Byzantine city wall during the first half of the $5^{\text {th }}$ century CE, apparently by the Empress Eudocia, who visited the city as a pilgrim in $438 \mathrm{CE}$ and returned to live there during the years 441-460 CE (Fig. 3; Table 1, no. 23) [47, pp. ${ }^{\star} 1,{ }^{\star} 10$ ]. The bird has a short crest and a short tail and could be a representative of the Phasianidae, or alternatively a cock, or a simplified peacock. A fragment from the Ophel excavations is most likely to be attributed to the same type of flask (Table 1, no. 24) [17, fig. 1.5.1:194]. The central motif of the small rosette on the flask from the Peristyle House is similar to the larger rosette on a flask in the Damascus National Museum; here, the rosette is formed of rays with dots in between, surrounded by two schematic wreaths (Table 1, no. 25) [15, no. 121].

Rosettes have a long tradition as a common decorative element in the visual arts from the late Second Temple period onwards and throughout the Byzantine period (Table 1, nos. 26-28). It has been suggested that the four-petalled rosette on no. 26 represents a cross; interestingly, such a rosette fills an arcade of three arches on a 'Kerb-

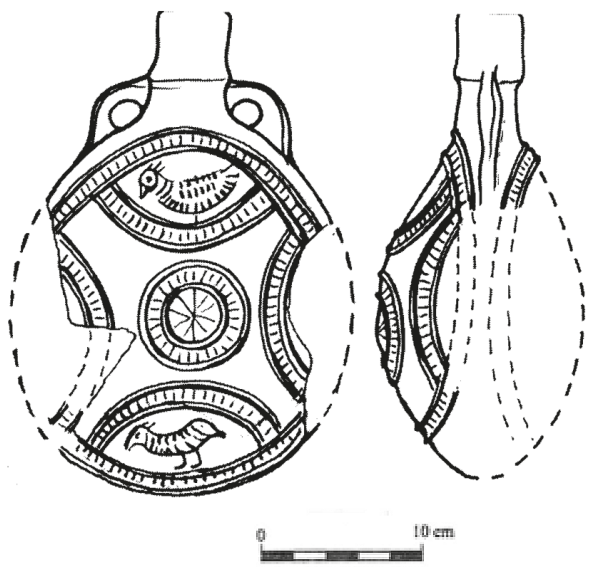

Fig. 2. Flask (now lost) from the Peristyle House south of the Temple Mount (Tyropoeon Valley). After [31, fig. 15.3:27] 


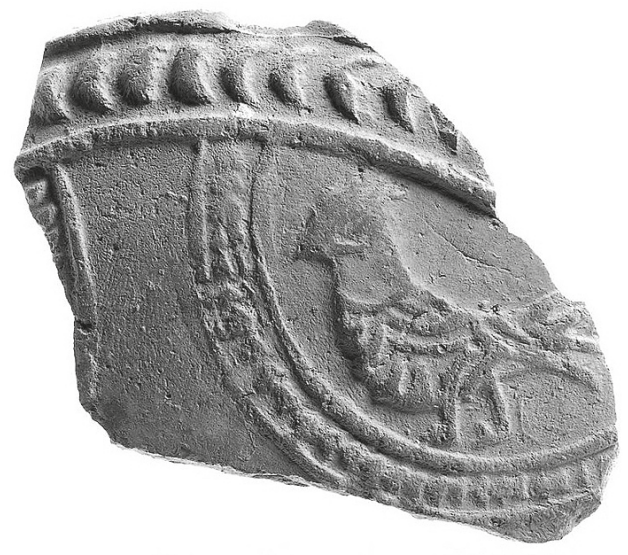

Fig. 3. Fragment of a flask from Mount Zion. Photo Clara Amit, Israel Antiquities Authority
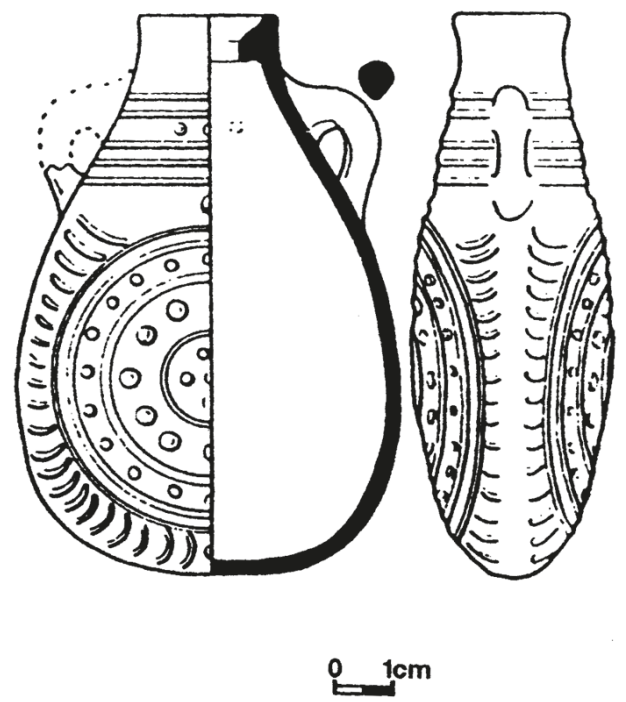

Fig. 4. Flask from Ramat Rahel. After [1, fig. 9:10] schnitt' vessel from Beth Shean, dated to the early Muslim period and considered Christian [41, p. 23]. Three concentric circles filled with raised dots is the central feature of an ampulla from Ramat Rahel (Fig. 4; Table 1, no. 29). The dating of the latter to the $7^{\text {th }}$ and early $8^{\text {th }}$ centuries on the basis of the similar decoration on oil lamps is not convincing. The mould-made vessel is decorated in the linear style of late Roman and early Byzantine lamps which appear to be the prototype of Late Byzantine - Early Islamic lamps [see, for example, 1, fig. 10:7, 9; 46, p. 110, no. 447 and p. 127, no. 525]. Small fragments of five flasks from Jerusalem and Capernaum can be attributed to Group 4 (Table1, nos. 30-34).

\section{Group 5 - plain flasks}

Plain vessels are included in the class of pilgrim flasks on the basis of form and fabric (Table 1, nos.35-36), though without secure contexts their function and use cannot be determined.

Another class of small containers not particularly common can be compared to the flasks. These are spouted juglets with a single handle generally described as lamp-fillers or baby-feeders. Judging by fabric and elements of iconography and decoration it appears that they, to all likelihood, were manufactured in the same workshops as the flasks [21, p.249]. The vessels are decorated with human faces, birds, palm branches, beaded circles and rows of chevrons. An example is a vessel (height $9.9 \mathrm{~cm}$ ), acquired in 1938 in Jerusalem (Fig. 5) [46, p. 168 , no. $694 ; 47$, p. ${ }^{*} 4$, fig. 8 ]. It is decorated with a large face in Orientalizing style with two birds above it, set antithetically on each side of the spout. The characteristic features of the face are the large flattened nose to which heavy, arched eyebrows are connected. The mouth is relatively small and the hair is indicated by short diagonal lines in a sche- 
matic pattern. Similar heads adorn a spouted juglet from Gezer [21, pp. 208, 226b] and two juglets without spouts in the collection of the Israel Antiquities $\mathrm{Au}$ thority [21, pp. 208, $226 \mathrm{~d}$, e].

In excavations at Nazareth a complete juglet with a spout (height $11 \mathrm{~cm}$ ) came to light, decorated with a geometric pattern of semi-circular bands filled with dots and vertical strokes [4, 277-280, fig. 220:1, pl. V, $3]$. With a suggested dating in the $3^{\text {rd }}$ or the beginning of the $4^{\text {th }}$ centuries, the decoration is similar to that on some ampullae of Group 4 (see Table 1, nos. 22-24, 29). The find-spot Cistern 51 is situated to the north of the Church of Annunciation and did not contain exclusively vessels for drawing water [4, 70-71, fig. 33 on p.68]. Other find-spots of spouted juglets or their fragments come from burials in Castra [57, p. 24) and Qiryat Ata [53, pp.139-140, fig.7:3]. At the Christian pilgrimage site of Capernaum, fragments of half a dozen juglets were retrieved, described by the excavator as ampullae with a single handle and dated to the first

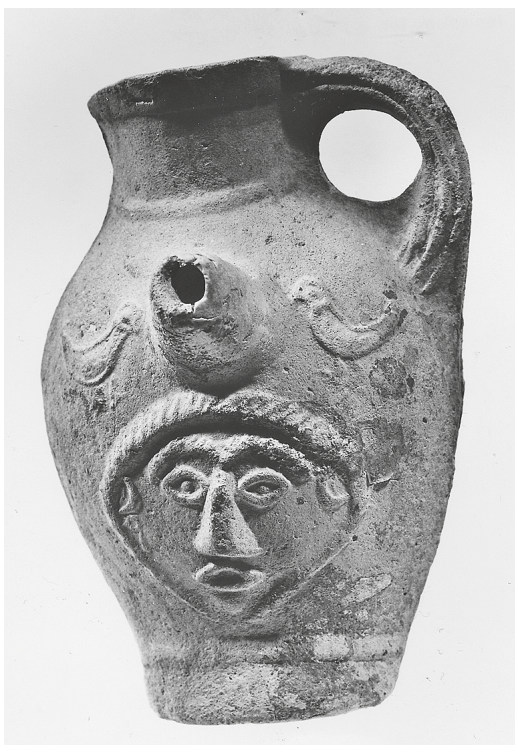

Fig. 5. Spouted juglet. Photo Zeev Radovan half of $6^{\text {th }}$ century [24, pp. 171-172; 25, p. 135, DG 155.1:2, 4; p. 136, DG 155.1:12, 14; 26, p. 82, DF 841:8-11, 16, 18].

Clay stamps for bread and tokens made of clay, earth, stone, or metal represent two additional classes of sacred objects. The Eucharistic stamped bread (prosphoron) was given to congregants after the service and taken home by pilgrims as blessed object. A mosaic floor in the southern funerary chapel of the Memorial of Moses on Mount Nebo, dated to the second half of the $4^{\text {th }}$ century CE, carries an inscription mentioning prosphora [39, p. 144, fig. 180]. A clay stamp with a diameter of $10 \mathrm{~cm}$ from Khirbet Deir Dusawi near Gaza depicts Mary seated with

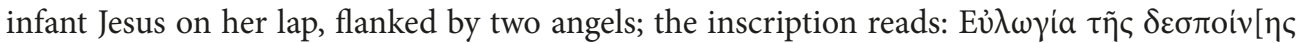

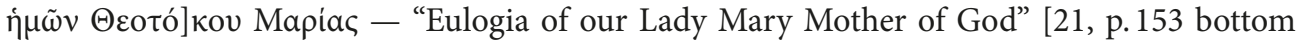
row; 43, p. 106, fig. 1, pl.28A-C]. The imagery has a parallel on a lead flask in Cologne, both sides adorned with Mary and the Infant flanked by two angels [14, pp. 156-157, pl. 7 a, b], on a token in the Royal Ontario Museum, Toronto, [21, p. 153 top row right] and on a lead plaque in Dumbarton Oaks, Washington Mary is [21, p. 153 top row centre and left]. By subject matter, the bread stamp from Khirbet Deit Dusawi could be related to the sanctuaries in Jerusalem, Bethlehem, Ain Kerem, or Nazareth. Rahmani argues that it is unlikely that the stamp originated from any of these holy sites and suggests that it should be attributed to a local artist who copied the scene from the central apse mosaic of the Church of St. Sergius at Gaza, which, according to Choricius of Gaza, contained a mosaic depicting Mary and the Child [43, p. 108; for a discussion on the relationship between monumental prototypes and depictions on objects of minor art see 13, pp. 22-25].

Excavations at Caesarea yielded an inscribed clay stamp with a diameter of $10.4 \mathrm{~cm}$ [10, p. 33; 35, pp.21-23, figs.1-3]. The fragmentary inscription is restored to Eủoyía K(vpiov) 


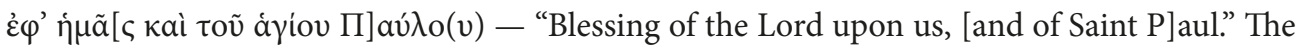
find presumably refers to a local shrine dedicated to Paul the Apostle $[9 ; 34]$. With about thirty stamps known so far, few depict Christian subjects and few are inscribed, and the variety in shape and design is great. In her study, Di Segni presents a list of nine stone and five clay stamps (including the above mentioned example from Khirbet Deir Dusawi) which were found in urban and rural sites of the Holy Land [10, p. 35]. Four clay stamps, one excavated at Tiberias and three unpublished ones in the collections of the Israel Antiquities Authority can be added [15]. In her recent publication, Kakish discusses twelve clay and stone stamps from Jordan, including two listed already by Di Segni [22].

Tokens (tortae) are lumps of earth or clay taken from holy places and decorated with several series of locus sanctus scenes referring to the events that occurred at the sites where they were acquired and taken home [21, p.211]. Tokens can also be made of silver and lead (the silver token from Caesarea with the Annunciation is mentioned above). A group of clay tokens came to light in situ on the floor of a mansion at Beth Shean, alongside coins of Justinian II, an emperor from 685-685 and 705-711 CE [45]. A popular subject is the Adoration of the Magi, related to the Church of the Nativity in Bethlehem [2, p. 143, no.37; 21, pp. 212 centre row right, 226; 44; 45, p. 122 , token F, diameter $5 \mathrm{~cm}$ ]. Other subjects on tokens from Beth Shean include the Ascension of Jesus [21, p. 212, bottom row left] and the Apparition of Jesus on the road to Emmaus [21, p.212, centre row left]. A token from Samaria with the Baptism of Jesus is assigned to the Church of St. John the Baptist, Samaria [21, p. 212, bottom row right; see also the imagery on lead flasks in Bonn and Berlin, 13, pp.13-14, 16, pls. 1a, 8e]. The Transfiguration scene is depicted on a clay token said to be from the Ramallah area, inscribed "Eulogia of Mount Tabor" [28, pl.46]. Ninety-three clay tokens with twelve different Christian subjects were found in a glass dish, said to originate from the pilgrimage site of St. Simeon Stylites the Elder [50, pp. 76-77; 21, p. 210]. Additional tokens are referred to in the publications cited, yet from the list presented it becomes apparent that there is a fair range of New Testament themes. According to Vikan, their popularity is related to pilgrimage and travel, the token transformed into an amulet protecting its bearer against danger and evil [50, pp. 81-87].

To sum: Apart from defining the flasks and spouted juglets, the bread stamps and tokens as pilgrim mementoes we have little information about their use and function in daily life and no information on workshops and how manufacture, distribution and sale were organized. Whether the production was ecclesiastically controlled, as suggested by some scholars, cannot be ascertained. The majority of finds were retrieved in fills; for several a domestic context is likely, others came from a monastery, a bathhouse, or were grave offerings. Hence, the findspots indicate that such objects were not primarily acquired by pilgrims visiting Holy Land sites. Rather, the locally produced artefacts were sold to local pilgrims at the holy sites and the local population acquired them for households out of private devoutness on a regular basis. For the prevalent Byzantine slipper lamps, many inscribed with the phrase 'The light of Christ shines beautifully for all' Magness convincingly suggested the same use as eulogiai [28].

Production: The clay flasks, juglets, bread stamps, and tokens exhibit some differences with regard to fabric, size, shape, style, imagery, and elements of decoration and hence must origi- 
nate from various local workshops. Altogether, they combine characteristic features and display visual images common in the Holy Land in the Late Roman and Byzantine periods. Of the fourteen flasks with a height range from $7-13.5 \mathrm{~cm}$ six are $9.5-10.5 \mathrm{~cm}$ in height (see Table 2).

Iconography: The objects comprise figurative scenes of the Old and the New Testament subjects like the Sacrifice of Isaac, Daniel in the Lions' Den and scenes from the lives of Elizabeth, Mary and Jesus. Equally common are the objects decorated with crosses, rosettes, and various geometric designs, while motifs such as birds and heads in Orientalizing style are relatively rare. The identification of the heads is not clear. However, considering that the artefacts were acquired and kept at home by Christian believers as mementoes of magical and prophylactic value, it is unlikely that the faces were purely decorative.

Use: In her recent study on Menas ampullae Witt summarizes different suggestions for the use of eulogiai [55, pp.13-15]. It is not clear whether the term 'eulogia' refers to the vessel or to the contents, yet, in any case, these objects represented an alternative solution since relics could not be acquired by everybody. In literary sources, the possible contents mentioned include oil, candle wax, and water as well as dust and earth scooped up near holy sites and tombs [see 50, p. 75 for an account of a miracle at sea performed by Dorotheos, priest and monk at the monastery of St. Simeon Stylites the Younger, who carried with him dust from the saint's shrine as eulogia]. There is textual evidence for oil collected from lamps that burnt at shrines, for oil in contact with relics and for oil said to be dripping from relics [13, pp.11-13]. On some flasks of the Monza-Bobbio class, an inscription makes a reference to oil from wood of the Cross or the Tree of Life [14, pp. 154, 157, 166, pls. 6a, 8c; 23, pp. 232-234]. The sparse textual evidence refers to vessels hung above the bed, worn around the neck and fastened to a belt [13, p. 12; 14 , p. 169; 23, p. 239; 52, p. 70; 55, p. 15]. Remains of leather cords tied around the neck of lead flasks are rare [14, 6a, 7, 8d; 23, pls. 25-26]. The assumption that lead and clay ampullae were attached to a necklace should be taken with a pinch of salt; even wearing small lead flasks of $6 \mathrm{~cm}$ as pendant is not convenient, let alone clay flasks of $10 \mathrm{~cm}$. The deposition of an ampulla in burials at Einabus (Table 1, no. 18) and Castra (Table 1, no. 20), placed as personal grave gifts, underlines the importance of such objects for the living and the dead. Unfortunately, none of the fragmentary vessels retrieved in domestic contexts permits a contextualization. The fragmentary flask from Khirbet Es-Suyyagh is the only find from a monastic site (Table 1, no. 11). Image-bearing eulogiai such as the flask with the Annunciation scene, attributed to a workshop in Nazareth (Table 1, no.4), can only tentatively be assigned to the specific sacred site referred to in the imagery.

Distribution: When referring to pilgrim mementoes, the obvious connotation is that such artefacts were brought home by pilgrims visiting shrines and sanctuaries away from their hometowns. In this way, a small number of flasks from Egypt, Syria, and Asia Minor reached Jerusalem, Ashqelon, Ashdod, Caesarea, and Beth Shean [21, pp. 202-203]. Vice versa, more than 50 lead, tin and silvered ampullae in the style of the Monza-Bobbio flasks left the Holy Land $[13 ; 14 ; 23 ; 51$, pp. 236-243; 52, pp. 36-40]. To date, no lead flask of this group came to light in excavations in the Holy Land, and it can be postulated that they were locally manufac- 
tured for pilgrims visiting from abroad. However, the artefacts discussed here form a different category. Produced in local workshops in the Holy Land they were acquired by local Christian believers on pilgrimage to local shrines at home or overland and were not dispersed throughout the Byzantine Empire. So far, to my knowledge, only a single fragmentary flask of this class was acquired in Egypt, it was published as originating from Asia Minor (Table 1, no. 9). Either the object was brought back from Jerusalem to Egypt by a pilgrim in ancient times or, alternatively, it could be the result of the modern trade of antiquities. Admittedly, the evidence has been so far fragmentary, and it is hoped that future research will help to clarify the interpretations presented here.

Table 2. The size of ampullae

\begin{tabular}{|c|c|}
\hline Nos. & $\begin{array}{c}\text { Height in cm/ } \\
\text { PH - Preserved height }\end{array}$ \\
\hline 18,21 & 7 \\
\hline 36 & 7.5 \\
\hline 8 & PH 8 \\
\hline 13 & PH 8.1 \\
\hline 25,28 & 9.5 \\
\hline $4-5,7$ & 10 \\
\hline 26 & 10.5 \\
\hline 12 & 11.5 \\
\hline 20 & 12 \\
\hline 17 & 13.5 \\
\hline
\end{tabular}

\section{References}

1. Aharoni Y. Excavations at Ramat Rahel, Seasons 1961 and 1962. Rome, Centro di studi semitici Publ., 1964. $124 \mathrm{p}$.

2. Bagatti B. Eulogie Palestinensi. Orientalia Christiana Periodica, 1949, vol. 15, pp. 126-166 (in Italian).

3. Bagatti B. Léglise de la gentilité en Palestine ( $1^{\text {er }}-X^{e}$ siècle). Jerusalem, Inprimerie des PP. Franciscains Publ., 1968. 357 p. (in French).

4. Bagatti B. Excavations in Nazareth. Vol.I. From the Beginning till the $12^{\text {th }}$ Century. Jerusalem, Franciscan Printing Press, 1969. 326 p.

5. Bagatti B. Nuovi elementi di scavo alla "Torre" del Sion. Liber Annuus, 1970, vol. 20, pp. 224-246 (in Italian).

6. Bliss F. J.; Dickie A. C. Excavations at Jerusalem (1894-1897). London, Committee of the Palestine Exploration Fund Publ., 1898. 374 p.

7. Crowfoot J. W.; Fitzgerald G. M. Excavations in the Tyropoeon Valley, Jerusalem 1927. Annual of the Palestine Exploration Fund V.London, Office of the Fund Publ., 1929. 135 p.

8. De Vincenz A. The Pottery Assemblage from the Bathhouse. Mazar E. The Temple Mount Excavations in Jerusalem 1968-1978 Directed by Benjamin Mazar. Final Reports. Vol. 4. The Tenth Legion in Aelia Capitolina (Qedem 52). Jerusalem, Keterpress Enterprises Publ., 2011, pp. 85-117.

9. Di Segni L. A Chapel of St. Paul at Caesarea Maritima? The Inscriptions. Liber Annuus, 2000, vol.50, pp. 383-400. 
10. Di Segni L. Inscription on a Eulogia Stamp. Israel Museum Studies in Archaeology, 2002, vol. 1, pp. 33-38.

11. Di Segni L. Greek Inscriptions from Area XV. Mazar E. The Temple Mount Excavations in Jerusalem 1968-1978 Directed by Benjamin Mazar. Final Reports. Vol. 2. The Byzantine and Early Islamic Periods (Qedem 43). Jerusalem, Keterpress Enterprises Publ., 2003, pp. 120-126.

12. Di Segni L. A Fragment of an Ampulla. Mazar E. The Temple Mount Excavations in Jerusalem 1968-1978 Directed by Benjamin Mazar. Final Reports. Vol.3. The Byzantine Period (Qedem 46). Jerusalem, Keterpress Enterprises Publ., 2007, pp. 35-36.

13. Engemann J. Palästinenische frühchristliche Pilgerandenken im F. Dölger-Institut in Bonn. Jahrbuch für Antike und Christentum, 1973, vol. 16, pp.1-27 (in German).

14. Engemann J.Palästinenische frühchristliche Pilgerampullen. Erstveröffentlichungen und Berichtigungen. Jahrbuch für Antike und Christentum, 2002, vol. 45, pp. 153-169 (in German).

15. Fansa M.; Bollmann B. (eds.). Die Kunst der frühen Christen in Syrien. Zeichen, Bilder und Symbole vom 4. bis 7. Jahrhundert. Mainz, von Zabern Publ., 2008. 218 p. (in German).

16. Feig N. A Byzantine Bread Stamp from Tiberias. Liber Annuus, 1994, vol. 44, pp. 591-594.

17. Fleitman Y.H.; Mazar E. The Late Roman and Byzantine Pottery from the 2012-2013 Excavation Seasons: Areas Upper A, B and C. Mazar E. The Ophel Excavations to the South of the Temple Mount 2009-2013. Final Reports, vol. 1. Jerusalem, Shoham Academic Research and Publication Publ., 2015, pp. 211-291.

18. Hachlili R. Ancient Jewish Art and Archaeology in the Land of Israel. Leiden, Brill Publ., 1988. 427 p.

19. Hayes J. W. Roman Pottery in the Royal Ontario Museum. A Catalogue. Toronto, The Royal Ontario Museum Publ., 1976. 125 p.

20. Israeli Y. Christian Ampulla. Highlights of Archaeology: The Israel Museum. Jerusalem, The Israel Museum Publ., 1984, pp. 112-113.

21. Israeli Y.; Mevorah D. (eds.). The Cradle of Christianity. The Israel Museum, Jerusalem, Cat. No. 438. Jerusalem, The Israel Museum Publ., 2000. 232 p.

22. Kakish A. Ancient Bread Stamps from Jordan. Mediterranean Archaeology and Archaeometry, 2014, vol. 14.2, pp. 19-31.

23. Kötzsche-Breitenbruch L. Pilgerandenken aus dem Heiligen Land. Drei Neuerwerbungen des Württembergischen Landesmuseums in Stuttgart. Vivarium. Festschrift Theodor Klauser zum 90. Geburtstag. Jahrbuch für Antike und Christentum Ergänzungsband 11. Münster; Aschendorff, 1984, pp.229-246 (in German).

24. Loffreda S. Cafarnao VI. Tipologie e contesti stratigrafici della ceramica (1968-2003). Collectio Maior 48. Jerusalem, Edizioni Terra Santa Publ., 2008. 396 p. (in Italian).

25. Loffreda S. Cafarnao VII. Documentazione grafica della ceramica (1968-2003). Collectio Maior 49. Jerusalem, Edizioni Terra Santa Publ., 2008. 346 p. (in Italian).

26. Loffreda S. Cafarnao VIII. Documentazione fotografica degli oggetti (1968-2003). Collectio maior 50. Jerusalem, Edizioni Terra Santa Publ., 2008. 151 p. (in Italian).

27. Magness J. Jerusalem Ceramic Chronology circa 200-800 CE. Sheffield, Sheffield Academic Press Publ., 1993. $273 \mathrm{p}$.

28. Magness J. Blessings from Jerusalem: Evidence for Early Christian Pilgrimage. Eretz-Israel, 1996, vol.25, pp. 37-45.

29. Manns F. Un sceau de la transfiguration. Liber Annuus, 1975, vol. 25, pp. 164-170.

30. Martin Nagy R. Pilgrim Ampullae. Sepphoris in Galilee: Crosscurrents of Culture. R. Martin Nagy; C. L. Meyers; E. M. Meyers; Z. Weiss (eds.). Winona Lake, Indiana, North Carolina Museum of Art Publ., 1996. 209 p.

31. Mazar E.; Gordon B. The Pottery from the Peristyle and Southern Houses. Mazar E. The Temple Mount Excavations in Jerusalem 1968-1978 Directed by Benjamin Mazar. Final Reports. Vol. 3. The Byzantine Period (Qedem 46). Jerusalem, Keterpress Enterprises Publ., 2007, pp. 149-176.

32. Mazar E.; Peleg. O. The Pottery Assemblage in the Large Byzantine Structure in Area XV. Mazar E. The Temple Mount Excavations in Jerusalem 1968-1978 Directed by Benjamin Mazar. Final Reports. Vol. 2. The Byzantine and Early Islamic Periods (Qedem 43). Jerusalem, Keterpress Enterprises Publ., 2003, pp. 86-103.

33. Metzger C. Les ampoules à eulogie du musée de Louvre. Paris, Ministère de la Culture, Editions Réunion des musées nationaux Publ., 1981. 124 p. (in French).

34. Patrich J. A Chapel of St. Paul at Caesarea Maritima? Liber Annuus, 2000, vol. 50, pp. 363-382.

35. Patrich J. Four Christian Objects from Caesarea Maritima. Israel Museum Studies in Archaeology, 2002, vol. 1, pp. 21-32. 
36. Patrich J.; Pinkas S. Lamps and Flask Molds. Patrich J. Archaeological Excavations at Caesarea Maritima. Areas CC, KK and NN. Final Reports. Vol. 1. The Objects. Jerusalem, Israel Exploration Society Publ., 2008, pp. 296-300.

37. Piccirillo M. Uno stampo per eulogia trovato a Gerusalemme. Liber Annuus, 1994, vol. 44, pp. 585-590 (in Italian).

38. Piccirillo M. Churches in Jerusalem. Jerusalem before Islam (BAR International Series 1699). Z. Kafafi; R. Schick (eds.). Oxford, Archaeopress Publ., 2007, pp. 189-199.

39. Piccirillo M. The Mosaics of Jordan. Amman, American Center of Oriental Research Publ., 2008. 383 p.

40. Piccirillo M.; Alliata E. The Madaba Map Centenary 1887-1997. Travelling through the Byzantine Umayyad Period, Proceedings of the International Conference Held in Amman, 7-9 April 1997 (SBF Collectio Maior 40). Jerusalem, Studium Biblicum Franciscanum Publ., 1999. 278 p.

41. Pickett J. Domestic Devotions in Late Antique Beth Shean. Expedition, 2013, vol.55, pp. 21-23.

42. Rahmani L. Y. Two Early Christian Ampullae. Israel Exploration Journal, 1966, vol. 16, pp. 71-74.

43. Rahmani L. Y. A Eulogia Stamp from the Gaza Region. Israel Exploration Journal, 1970, vol. 20, pp. 105-108.

44. Rahmani L. Y. The Adoration of the Magi on Two Sixth-Century CE Eulogia Tokens. Israel Exploration Journal, 1979, vol.29, pp.34-36.

45. Rahmani L. Y. Eulogia Tokens from Byzantine Beth She'an. 'Atiqot, 1993, vol. 22, pp. 109-119.

46. Rosenthal R.; Sivan R. Ancient Lamps in the Schloessinger Collection (Qedem 8). Jerusalem, Keterpress Enterprises Publ., 1978. 179 p.

47. Rosenthal-Heginbottom R.; Zelinger Y. Application-decorated Pottery from Mount Zion, Jerusalem. Arise, Walk Through the Land. Studies in the Archaeology and History of the Land of Israel in Memory of Yizhar Hirschfeld on the Tenth Anniversary of His Demise. J. Patrich; O. Peleg-Barkat; E. Ben-Yosef (eds.). Jerusalem, Israel Exploration Society Publ., 2016, pp. 89-101.

48. Strube C. Pilgerflasche. Land des Baal. Syrien - Forum der Völker und Kulturen. Museum für Vor- und Frühgeschichte, Berlin. Mainz, von Zabern Publ., 1982, pp. 244-245.

49. Taxel I. Khirbet Es-Suyyah: A Byzantine Monastery in the Judaean Shephelah (Salvage Excavation Report 6). Tel Aviv, University Press Publ., 2009. 261 p.

50. Vikan G. "Guided by Land and Sea": Pilgrim Art and Pilgrim Travel in Early Byzantium. Jahrbuch für Antike und Christentum Ergänzungsband 18. Münster, Aschendorff Publ., 1991, pp.74-92.

51. Vikan G. Byzantine Pilgrims' Art. Sacred Images and Sacred Power in Byzantium V (Variorum collected studies series). Aldershot; Burlington, Ashgate Publ., 2003, pp. 229-266.

52. Vikan G. Early Byzantine Pilgrimage Art. Washington D.C., Dumbarton Oaks Research Library and Collection Publ., 2010. 109 p.

53. Vitto F. A. Late Third-Fourth-Century CE Burial Cave on Remez Street, Qiryat Ata. Atiqot, 2008, vol.60, pp. 165-176.

54. Wamser L.; Zahlhaas G. (eds.). Rom und Byzanz, Archäologische Kostbarkeiten aus Bayern. Munich, Hirmer Verlag Publ., 1998. 256 p. (in German).

55. Witt J. Werke der Alltagskultur. Teil 1: Menasampullen. Staatliche Museen zu Berlin - Preußischer Kulturbesitz. Skulpturensammlung und Museum für Byzantinische Kunst. Bestandskatalog, vol. 2. Wiesbaden, Reichert Verlag Publ., 2000. 178 p. (in German).

56. Wulff $\mathrm{O}$. Altchristliche und mittelalterliche byzantinische und italienische Bildwerke. Beschreibung der Bildwerke der christlichen Epochen. Teil 1: Altchristliche Bildwerke. Text und Tafeln. Berlin, Verlag Georg Reimer Publ., 1909. 336 p. (in German).

57. Zemer A. Castra at the Foot of Mount Carmel: The City and Its Secrets. Catalogue of the National Maritime Museum. Haifa, National Maritime Museum Publ., 1999. 73 p.

Title. Pilgrim Mementoes from the Holy Land: Production, Iconography, Use, and Distribution.

Author. Renate Rosenthal-Heginbottom - Ph. D., independent researcher. Am Strohberg 7, 24191 Grossolt, Germany. renate34@gmx.de

Abstract. With the growing number of Christian pilgrims visiting the Holy Land the demand for sacred and magical mementoes rose. Local workshops were established, where craftsmen produced flasks and spouted juglets, bread stamps, and tokens. Mostly made of clay, they were cheap keepsakes produced and sold at and near shrines and sanctuaries. The subjects depicted are related to the sites and drawn from images at the holy places. The class documented best are flasks, including moulds; it is possible to define five distinct stylistic and iconographic groups. In imagery and elements of decoration they combine characteristic features of the 
Byzantine visual arts prevalent in the Holy Land. The find-spots indicate that such objects were not primarily acquired by pilgrims visiting Holy Land sites. Rather, they were sold to local pilgrims at the holy sites and the local population acquired them for household use out of private devoutness on a regular basis. Probably they were low-priced cousins of the metal ampullae in the style of the widely exported Monza/Bobbio flasks.

Keywords: pilgrimage art; moulds; eulogiai; ampullae; bread stamps; tokens; Biblical themes; New Testament scenes.

Название статьи. Паломнические реликвии со Святой земли: Производство, иконография, использование и распространение.

Сведения об авторе. Розенталь-Хегинботтом Рената - Ph. D., независимый исследователь. Строхберг, 7, Гроссольт, Германия, 24191. renate34@gmx.de

Аннотация. C IV в. увеличивается количество паломников, прибывающих в Святую землю. Стремление паломников привезти оттуда какие-либо реликвии приводит к появлению местных мастерских, специализирующихся на производстве подобных предметов. Среди них были глиняные и стеклянные сосуды, евлогии, ювелирные произведения и прочие недорогие памятные вещи, которые изготавливались и продавались неподалеку от храмов и усыпальниц. Представленные на них изображения были тем или иным образом связаны с местом, память о котором они должны были сохранять.

Такие вещи могли восходить к художественным произведениям, исполненным с высочайшим мастерством. Соответствующие обычаи описаны в дневнике Эгерии, посетившей Святую землю около 380 г., и у паломника из Пьяченцы (ок. 570 г., имя его неизвестно), который сообщает: «они предлагают масло для освящения в маленьких сосудах». Паломники привозили домой подобные сосуды с освященной водой, маслом и иными жидкостями и хранили их как чудодейственные реликвии, оберегающие от зла и обладающие целительной силой. На материале немногочисленных археологических находок и предметов из музейных собраний (приблизительно три десятка сосудов) можно выделить четыре различных стилистических и иконографических типа декора: 1) сочетающий радиальные и концентрические элементы; 2) изображения, расположенные рядами; 3) библейские сюжеты и изречения; 4) сосуды, лишенные декоративного оформления. Среди них есть группы предметов, различных по материалу, размеру, форме, стилю, изображениям, элементам декора. Весьма вероятно, что они происходят из различных иерусалимских мастерских, прочие же были созданы в иных центрах, каких именно - остается неизвестным. Использование изображений и декоративных элементов также характерно для оформления светильников, небольших кувшинов, евлогий. Некоторые сосуды были найдены среди мусора. Какие-то из них могли использоваться в быту. Один был обнаружен на территории монастыря, другие - в банях и погребениях.

Таким образом, очевидно, что сосуды приобретали не только паломники, но и местное население, использовавшее их дома для определенных обрядов, как и подсвечники с радиальным декором и надписями. Характерным декоративным мотивом в украшении ампул, глубоких чаш, кувшинов и светильников являются фронтальные головы и лица. Возникает вопрос: имели ли эти изображения символическое значение для владельцев или же выполняли сугубо декоративные функции? Не имея возможности ответить на него однозначно, мы выдвигаем предположение, что эти головы, изображавшиеся на сакрально значимых предметах, стали привычным элементом в позднеримской и византийской Палестине, где они появляются уже на сосудах II в. н. э., украшенных накладками и сделанных из местной глины. Их производство было связано с новыми техниками, привнесенными римскими гончарами после 70 г. н.э.

В III в. этот тип становится распространенным. Такие сосуды производились не только в мастерских Элии Капитолины, но и в сельских областях, о чем свидетельствует обнаружение керамической мастерской III-IV вв. на юго-востоке Иерусалима. Эти изображения голов в восточном духе с характерными чертами лица восходят к давним ближневосточным традициям. Простые украшения, такие как розетки, круги с бусами и венки, продолжают возникшую до 70 г. н. э. традицию иудейского искусства периода Второго храма.

В заключение следует отметить, что производство священных предметов на Святой земле было, с одной стороны, новшеством, а с другой стороны, было укоренено в местных дохристианских обычаях, в особенности иудейских. Более того, глиняные сосуды - дешевые аналоги металлических ампул типа ампул Монцы и Боббио - были востребованы, прежде всего, местным населением.

Ключевые слова: реликвии паломников; формы для выпечки просфор; штампы для просфор; евлогия; ампула; талисман; библейские сюжеты; евангельские сюжеты. 